\title{
O PRINCÍPIO DA BOA-FÉ: DA SUA INSERÇÃO NO DIREITO CIVIL BRASILEIRO E A SUA RELAÇÃO COM OS CONTRATOS
}

\author{
THE PRINCIPLE OF GOOD FAITH: OF ITS \\ INSTRUMENT IN BRAZILIAN CIVIL LAW AND \\ ITS RELATIONSHIP WITH CONTRACTS
}

\section{Daniel João Martins ${ }^{1}$}

Resumo: O princípio da boa-fé foi inserido de forma objetiva no atual Código Civil. Ele se apresenta como norma de conduta a ser observada nos negócios jurídicos. O objetivo deste estudo é elucidar sobre a inserção da boa-fé e demonstrar a sua relação com os contratos. O tema se faz relevante para a comunidade jurídica em geral, pois se trata de instituto de conteúdo moral importante para a convivência pacífica das pessoas. Aborda-se, sob o método dedutivo, a origem, as definições, a normatização, as classificações, as funções, os de- veres anexos e os desdobramentos da boa-fé. Infere-se que o postulado da boa-fé se relaciona aos contratos para assegurar valores, como lealdade, confiança e honestidade. Verifica-se que, dessa relação, surgem as condutas e os deveres que precisam ser observados pelos contratantes a fim de garantir uma proteção jurídica do negócio celebrado.

Palavras-chave: Boa-fé. Boa-fé objetiva. Probidade. Deveres anexos. Integração nos contratos.

Abstract: The principle of good faith was inserted objectively in

1 Pós-graduado em Direito Público, convênio com a Universidade Regional de Blumenau (FURB) e com a Escola Superior da Magistratura do Estado de Santa Catarina (ESMESC); residente judicial. E-mail: daniell.jm@outlook.com 
the current Civil Code. It presents itself as a norm of conduct to be observed in legal businesses. The purpose of this study is to elucidate the insertion of good faith and demonstrate its relationship with contracts. The theme becomes relevant to the legal community in general, because it is an institute of moral content important for the peaceful coexistence of people. The source, definitions, standardization, classifications, functions, attached duties and developments of good faith are discussed under the deductive method. It is inferred that the postulate of good faith relates to contracts to secure values such as loyalty, trust and honesty. It turns out that from this relationship arise the conduct and duties that need to be observed by the contractors in order to ensure legal protection of the business entered.

Keywords: Good faith. Objective good faith. Probity. Attached duties. Integration in contracts.

\section{INTRODUÇÃO}

A boa-fé é um dos postulados mais relevantes para a convivência social. O seu surgimento reporta para a mais longínqua época da história da humanidade. A partir disso, a presente pesquisa visa observar a inserção do princípio da boa-fé no direito civil brasileiro e a sua relação com os contratos.

O objetivo do presente artigo é realizar e apresentar um estudo investigativo sobre o tema proposto. Assim, procura-se saber como se inseriu a boa-fé no direito civil brasileiro e quais são as suas relações com o direito contratual.

O método a ser empregado é o dedutivo, sendo que o tema é abordado no seu conceito mais amplo para, no fim da pesquisa, responder ao problema proposto. A técnica utilizada é a pesquisa bibliográfica, buscando-se como referências doutrinadores, como Maria Helena Diniz, Sílvio de Salvo Venosa, Flávio Tartuce, Judith Martins-Costa, Pablo Stolze Gagliano, Rodolfo Pamplona Filho, entre outros, que poderão contribuir com a 
pesquisa. O trabalho científico apresenta-se em três seções, que são: o princípio da boa-fé, a boa-fé objetiva e suas funções no Código Civil e a boa-fé objetiva nos contratos.

O tema pesquisado é essencial para o direito civil brasileiro, pois esse princípio trata de valores, como: lealdade, confiança, agir corretamente, comportamento ético e probidade. Isso é extremamente relevante, pois são conceitos morais aplicados ao direito positivo. $\mathrm{O}$ estudo contribuirá para melhor entendimento do princípio da boa-fé na esfera das relações jurídicas, especialmente no âmbito contratual.

\section{O PRINCÍPIO DA BOA-FÉ}

A conduta das partes nas relações negociais sempre foi motivo de preocupação do direito. O princípio da boa-fé foi incluso ao ordenamento jurídico brasileiro com o intuito de trazer equilíbrio nas relações civis.

Maria Helena Diniz destaca que a boa-fé não está intimamente ligada à interpretação do contrato, mas sim ao interesse social de segurança das relações jurídicas que envolvem lealdade, honestidade, honradez e probidade entre as partes. A mesma doutrinadora também conclui que o princípio da boa-fé é uma norma que requer o comportamento leal e honesto das partes (DINIZ, 2016, p. 53).

Assim, na busca da melhor compreensão do princípio da boa-fé, trata-se, na sequência, sobre a sua origem, as principais definições doutrinárias, as disposições no Código Civil e demais legislações e a diferenciação entre boa-fé objetiva e boa-fé subjetiva.

\subsection{Origem do princípio da boa-fé}

Os princípios são preceitos jurídicos consagrados. Espécies de normas que se diferenciam das regras. Quanto às regras, de- 
pendem do pressuposto da validade. Os princípios são direcionamentos jurídicos que devem ser pesados aos casos concretos a eles impostos. São essenciais ao direito, pois os princípios têm o caráter de dar às regras o seu valor pretendido pelo ordenamento jurídico.

São diversas as explicações sobre a origem da boa-fé na história. Flávio Tartuce (2016, p. 94) narra a origem da boa-fé da seguinte maneira:

Contudo, desde os primórdios do direito romano, já se cogitava uma outra boa-fé, aquela direcionada à conduta das partes, principalmente nas relações negociais e contratuais. Com o surgimento do jusnaturalismo, a boa-fé ganhou, no Direito Comparado, uma nova faceta, relacionada com a conduta dos negociantes e denominada boa-fé objetiva.

O doutrinador supracitado afirma, em conclusão ao seu pensamento, que a boa-fé se originou da subjetivação e se transformou na objetivação. Assim, as codificações europeias, nas relações de direito privado, começaram a consolidar o elemento objeto da boa-fé.

Flávio Tartuce continua a ensinar que, com a evolução da ciência jurídica, alguns códigos da era moderna começaram a fazer menção à boa-fé objetiva. Pode-se citar: o Código Civil Português de 1966, o Código Civil Italiano de 1942 e o BGB Alemão de 1900 (TARTUCE, 2016, p. 94).

No Brasil, o princípio da boa-fé objetiva somente foi inserido no Código Civil de 2002. No Código Civil anterior, de 1916, apenas se trabalhava com a boa-fé subjetiva, a qual era ligada às questões possessórias.

O sistema que se procurou adotar no ordenamento brasileiro foi o semelhante ao adotado pelo Código Civil Italiano de 1942. Sobre isso, Flávio Tartuce (2016, p. 94) explica: 
Por certo é que adotou o Código Civil em vigor o princípio da eticidade, valorizando as condutas guiadas pela boa-fé, principalmente no campo obrigacional. Nossa codificação segue assim a sistemática do Código Civil italiano de 1942, que traz a previsão do preceito ético em vários dos seus dispositivos.

Sob a inspiração do Código Italiano e do dispositivo já existente no Código de Defesa do Consumidor, art. 4, inciso III, o Código Civil Brasileiro de 2002 implantou cláusulas abertas positivando o princípio da boa-fé. Essas cláusulas abertas são denominadas na doutrina civil como cláusulas gerais. Sobre isso, Sílvio de Salvo Venosa (2018, p. 20) esclarece:

Essa disposição constitui modalidade que a doutrina convencionou denominar cláusula geral. Essa rotulação não nos dá perfeita ideia do conteúdo. A cláusula geral não é, na verdade, geral. A denominação cláusulas abertas tem sido mais utilizada para essas hipóteses, dando ideia de um dispositivo que deve ser amoldado ao caso concreto, sob uma compreensão social e histórica.

Com isso, a legislação civil brasileira deixou a cargo dos julgadores o dever de intepretação, caso a caso, para a aplicação desse princípio. Sendo assim, cabe ao juiz ou ao árbitro o exame das condições em que o negócio foi firmado, o nível sociocultural dos contratantes, o período histórico e o momento econômico.

Antes de demonstrar os dispositivos da boa-fé no Código Civil atual, tratar-se-á, na sequência, sobre algumas definições doutrinárias do princípio em comento.

\subsection{Das principais definições doutrinárias da boa-fé}

Demonstram-se algumas definições e conceitos doutrinários sobre a boa-fé. Nota-se que cada doutrinador trará uma definição e um modo de explicação diferente, apesar de se re- 
ferir sobre o mesmo assunto. Essas distinções são decorrentes do fato de o instituto ser um princípio de caráter moral.

Maria Helena Diniz (2016, p. 55) sintetiza a boa-fé da seguinte maneira:

Segundo esse princípio, na interpretação do contrato, é preciso ater-se mais à intenção do que ao sentido literal da linguagem, e, em prol do interesse social de segurança das relações jurídicas, as partes deverão agir com lealdade e confiança recíprocas, auxiliando-se mutuamente na formação e na execução do contrato.

Já Carlos Roberto Gonçalves (2017, p. 54) define assim:

O princípio da boa-fé exige que as partes se comportem de forma correta não só durante as tratativas como também durante a formação e o cumprimento do contrato. Guarda relação com o princípio de direito segundo o qual ninguém pode beneficiar-se da própria torpeza.

Sílvio de Salvo Venosa (2018, p. 19) trata da seguinte forma:

[...] princípio da boa-fé se estampa pelo dever das partes de agir de forma correta, eticamente aceita, antes, durante e depois do contrato, isso porque, mesmo após o cumprimento de um contrato, podem sobrar-lhes efeitos residuais.

As definições apresentadas demonstram a preocupação com a conduta das partes envolvidas nos negócios jurídicos. Assim, observam-se termos, como: lealdade, confiança, agir corretamente, comportamento ético e probidade. Essas palavras expressam conceitos morais nos quais o julgador, ao resolver uma situação jurídica, deve aplicar. O pós-positivista Dworkin defende que há uma estreita relação entre Direito e Moral (DWORKIN apud ZANON JUNIOR, 2016, p. 233). 
Visto as definições doutrinárias, passar-se-á a estudar sobre os dispositivos da boa-fé no Código Civil e a sua presença em outras legislações dentro do ordenamento jurídico brasileiro.

\subsection{O princípio da boa-fé no Código Civil e nas demais legislações}

O Código Civil de 2002, ao introduzir o princípio da boafé, além de ter seguido a linha do direito comparado, baseouse inicialmente no dispositivo do Código de Defesa do Consumidor, instituído no ano de 1990. O Código de Defesa do Consumidor normatizou o seguinte:

Art. $4^{\circ}$ A Política Nacional das Relações de Consumo tem por objetivo o atendimento das necessidades dos consumidores, o respeito à sua dignidade, saúde e segurança, a proteção de seus interesses econômicos, a melhoria da sua qualidade de vida, bem como a transparência e harmonia das relações de consumo, atendidos os seguintes princípios: [...]

III - harmonização dos interesses dos participantes das relações de consumo e compatibilização da proteção do consumidor com a necessidade de desenvolvimento econômico e tecnológico, de modo a viabilizar os princípios nos quais se funda a ordem econômica (art. 170, da Constituição Federal), sempre com base na boa-fé e equilíbrio nas relações entre consumidores e fornecedores. (BRASIL, 1990, grifo nosso).

Por meio dos princípios norteadores que embasaram o legislador civil, além da socialidade e operabilidade, houve a inserção do princípio da eticidade, traduzindo o que hoje as doutrinas denominam de boa-fé objetiva. Esses postulados estão insculpidos nos arts. 113, 187 e 422, todos do Código Civil vigente, do qual se transcreve: 
Art. 113. Os negócios jurídicos devem ser interpretados conforme a boa-fé e os usos do lugar de sua celebração. $\S 1^{\circ} \mathrm{A}$ interpretação do negócio jurídico deve lhe atribuir o sentido que:

I - for confirmado pelo comportamento das partes posterior à celebração do negócio;

II - corresponder aos usos, costumes e práticas do mercado relativas ao tipo de negócio;

III - corresponder à boa-fé;

IV- for mais benéfico à parte que não redigiu o dispositivo, se identificável; e

$\mathrm{V}$ - corresponder a qual seria a razoável negociação das partes sobre a questão discutida, inferida das demais disposições do negócio e da racionalidade econômica das partes, consideradas as informações disponíveis no momento de sua celebração.

$\S 2^{\circ}$ As partes poderão livremente pactuar regras de interpretação, de preenchimento de lacunas e de integração dos negócios jurídicos diversas daquelas previstas em lei.

Art. 187. Também comete ato ilícito o titular de um direito que, ao exercê-lo, excede manifestamente os limites impostos pelo seu fim econômico ou social, pela boa-fé ou pelos bons costumes.

Art. 422. Os contratantes são obrigados a guardar, assim na conclusão do contrato, como em sua execução, os princípios de probidade e boa-fé. (BRASIL, 2002).

Sílvio de Salvo Venosa (2018, p. 21) esquematiza o princípio da boa-fé objetiva no Código Civil da seguinte forma:

Desse modo, pelo prisma do Código, há três funções nítidas no conceito de boa-fé objetiva: função interpretativa (art. 113); função de controle dos limites do exercício de um direito (art. 187); e função de integração do negócio jurídico (art. 422). 
Neste momento, objetiva-se demonstrar as normas positivadas inerentes à boa-fé no ordenamento jurídico brasileiro. As funções desse princípio, juntamente com a análise detalhada do art. 422 do Código Civil, serão tratadas nas seções seguintes.

A solidificação do instituto da boa-fé inspirou, inclusive, a sua inclusão no novo Código de Processo Civil, de 2015, como dever processual, in verbis: "Art. $5^{\circ}$. Aquele que de qualquer forma participa do processo deve comportar-se de acordo com a boa-fé." (BRASIL, 2015).

Nota-se que a boa-fé se tornou também princípio processual, obrigando as partes a agir com lealdade, honestidade, honradez e probidade dentro da relação processual.

Feitas essas referências à boa-fé no ordenamento jurídico brasileiro, passa-se à diferenciação entre boa-fé objetiva e boa-fé subjetiva.

\subsection{Diferença entre a boa-fé objetiva e a subjetiva}

O princípio da boa-fé é classificado em duas subdivisões: boa-fé subjetiva e boa-fé objetiva. Sobre isso, Carlos Roberto Gonçalves destaca que "o princípio da boa-fé se biparte em boa-fé subjetiva, também chamada de concepção psicológica da boa-fé, e boa-fé objetiva, também denominada concepção ética da boa-fé." (GONÇALVES, 2017, p. 55).

Observa-se que se pode estabelecer uma primeira diferenciação entre as classificações, observando-se o que foi citado anteriormente.

Pablo Stolze Gagliano e Rodolfo Pamplona Filho informam essa primeira diferenciação da seguinte forma: a boa-fé subjetiva "consiste em uma situação psicológica, um estado de ânimo ou de espírito do agente que realiza determinado ato ou vivência dada situação, sem ter ciência do vício que a inquina." (GAGLIANO; PAMPLONA FILHO, 2013, p. 100- 
101). Já a boa-fé objetiva "consiste em uma verdadeira regra de comportamento, de fundo ético e exigibilidade jurídica." (GAGLIANO; PAMPLONA FILHO, 2013, p.100 -101).

Elpídio Donizetti e Felipe Quintella (2016, p. 483) corroboram com a seguinte explicação:

A dita boa-fé subjetiva refere-se à esfera interna da pessoa. Opera em seu plano de consciência, e por isso se relaciona com a moral. O princípio da boa-fé, ou boa-fé objetiva, por sua vez, refere-se ao comportamento da pessoa. Por isso, opera no plano exterior, e, por conseguinte, insere-se na órbita jurídica.

Enquanto a boa-fé objetiva tem natureza de princípio, impondo que as partes ajam com honestidade, retidão e lealdade, a intepretação da boa-fé subjetiva parte da verificação da intenção do sujeito da relação jurídica. Assim, sobre a boa-fé subjetiva, Carlos Roberto Gonçalves ensina o que se expõe a seguir.

A aplicação da boa-fé subjetiva é apurada mais no campo dos direitos reais, especialmente em matéria possessória. Como exemplo de incidência da boa-fé subjetiva, tem-se: as hipóteses de casamento putativo, as hipóteses de aquisição da propriedade alheia mediante a usucapião, as errôneas situações do mandato aparente e as errôneas situações que envolvem o herdeiro aparente. Essa boa-fé era a única que existia no Código Civil de 1916, anterior ao Código Civil vigente.

A boa-fé objetiva, que foi inserida no atual Código Civil, encontra-se presente nos arts. 113, 187 e 422 . Ela é tida como regra de conduta na qual o juiz estabelece o comportamento que deveria ter sido adotado pelas partes envolvidas, naquelas circunstâncias levando em conta ainda os usos e os costumes.

Na seção seguinte, tratar-se-á com mais detalhes sobre a boa-fé objetiva e serão demonstradas as três funções decorrentes dos três dispositivos expressos no Código Civil. 


\section{A BOA-FÉ OBJETIVA E SUAS FUNÇÕES NO CÓDIGO CIVIL}

A boa-fé objetiva, inserida no Código Civil de 2002, constitui em norma jurídica fundada em um princípio geral do direito. Com isso, pode-se assegurar que todos devem comportar-se de boa-fé nas suas relações recíprocas.

Para Miguel Reale (apud DINIZ, 2016, p. 54), “a boa-fé é condição essencial à atividade ético-jurídica, caracterizando-se pela probidade dos seus participantes." Assim, para ele, a boa-fé objetiva é forma de conduta e norma de comportamento.

Pablo Stolze Gagliano e Rodolfo Pamplona Filho ensinam que, "em uma dada relação jurídica, presente o imperativo dessa espécie de boa-fé, as partes devem guardar entre si a lealdade e o respeito que se esperam do homem comum." (GAGLIANO; PAMPLONA FILHO; 2013, p.102). Contudo, pode-se afirmar que o princípio da boa-fé objetiva é uma verdadeira regra de conduta imposta entre as partes numa relação jurídica.

A boa-fé objetiva apresenta-se no Código Civil de 2002, como já demonstrado anteriormente, em três funções, as quais se passa a estudar a seguir.

\subsection{Função de intepretação, art. 113, caput e seus $\S \S$ $1^{0}$ e $2^{\mathbf{o}}$, do Código Civil}

A boa-fé objetiva é conduta que deve orientar todos os negócios jurídicos. O julgador, ao analisar um negócio jurídico, sempre deve interpretar à luz desse princípio. Maria Helena Diniz (2017, p. 205) leciona o seguinte:

O princípio da boa-fé objetiva está intimamente ligado não só à interpretação do negócio jurídico, pois, segundo ele, o sentido literal da linguagem não deverá prevalecer sobre a intenção inferida da declaração de vontade 
das partes, mas também ao interesse social da segurança das relações jurídicas, uma vez que as partes devem agir com lealdade, retidão e probidade, durante as negociações preliminares, a formação, execução e extinção do ato negocial, e também de conformidade com os usos do local em que o ato negocial foi por elas celebrado.

Assim, compreende-se que a intepretação é sempre para assegurar valores, como lealdade, retidão e probidade. O presente princípio deve ser levado em consideração pelo magistrado no caso de lacunas quanto ao direito obrigacional.

Sobre o artigo que inseriu a função interpretativa, Miguel Reale (apud GAGLIANO; PAMPLONA FILHO, 2013, p. 105) faz a seguinte explanação:

[...] em todo ordenamento jurídico há artigos-chave, isto é, normas fundantes que dão sentido às demais, sintetizando diretrizes válidas "para todo sistema". [...] Com razão, o supratranscrito art. 113 dá preferência aos negócios jurídicos para fixar as diretrizes hermenêutica da eticidade e da socialidade.

Recentemente, entrou em vigor a Lei n. 13.874 (Lei da liberdade econômica), de 20 de setembro de 2019, que incluiu os $\S \S 1^{\circ}$ e $2^{\circ}$ ao existente art. 113 do Código Civil. Destacase que a redação do caput do dispositivo legal permaneceu inalterada, sendo acrescentadas, com os parágrafos, diretrizes expressas de como se deve proceder para a interpretação dos negócios jurídicos.

Nesse contexto e com a ênfase trazida pelo novo inciso III, $\S 1^{\circ}$, do art. 113 do Código Civil, ficou evidenciado que a boa-fé objetiva é sempre relevante na interpretação de qualquer negócio jurídico. Entendido isso, passa-se à próxima função estampada no Código Civil de 2002. 


\subsection{Função de controle dos limites do exercício de um direito, art. 187 do Código Civil (abuso de direito)}

A função de controle decorrente da boa-fé objetiva tem por escopo a delimitação do exercício de direitos subjetivos. Pablo Stolze Gagliano e Rodolfo Pamplona Filho (2013, p. 112) doutrinam o seguinte:

Por meio da boa-fé objetiva, visa-se a evitar o exercício abusivo dos direitos subjetivos. Aliás, no atual sistema constitucional, em que se busca o desenvolvimento socioeconômico sem desvalorização da pessoa humana, não existe mais lugar para a "tirania dos direitos".

Essa prática, que pode surgir no exercício do direito subjetivo, se apresenta na doutrina civil como abuso de direito, a qual, inclusive, gera responsabilidade civil. Maria Helena Diniz (2017, p. 261) define abuso de direito da seguinte forma:

O uso de um direito, poder ou coisa além do permitido ou extrapolado as limitações jurídicas, lesando alguém, traz como efeito o dever de indenizar. Realmente, sob a aparência de um ato legal ou lícito, esconde-se a ilicitude (ou melhor, antijuridicidade sui generis) no resultado, por atentado ao princípio da boa-fé e aos bons costumes ou por desvio da finalidade socioeconômica para qual o direito foi estabelecido.

Com essa função de controle, pode-se dizer, conforme Cristoph Fabian, que: "Todo o direito é delimitado pela boa-fé. Fora ou contra a boa-fé não existe nenhum direito subjetivo. Tais interesses jurídicos não merecem proteção." (FABIAN apud GAGLIANO; PAMPLONA FILHO, 2013, p. 112). Desse modo, a boa-fé objetiva deve ser observada acima dos demais interesses.

Analisada a função de controle dos limites do exercício de um direito, passa-se a examinar a próxima função elencada no Código Civil de 2002, no qual essa função é a ligada aos contratos. 


\subsection{Função de integração nos contratos, art. 422 do Código Civil}

Como essa função é descrita no art. 422 do Código Civil de 2002, pode-se afirmar que a boa-fé objetiva integra a celebração do contrato. Pablo Stolze Gagliano e Rodolfo Pamplona Filho (2013, p. 102-103) explicam essa afirmativa da seguinte maneira:

Com isso, queremos dizer que, livrando-nos das amarras excessivamente tecnicistas da teoria clássica, cabe-nos fazer uma releitura da estrutura obrigacional, revista à luz dessa construção ética, para chegarmos à inafastável conclusão de que o contrato não se esgota apenas na obrigação principal de dar, fazer ou não fazer. Ladeando, pois, esse dever jurídico principal, a boa-fé objetiva impõe também a observância de deveres jurídicos anexos ou de proteção, não menos relevantes, a exemplo dos deveres de lealdade e confiança, assistência, confidencialidade ou sigilo, informação etc.

Percebe-se da citação que o contrato não se esgota apenas na obrigação principal de dar, fazer ou não fazer. Existem integrado ao contrato, por força da cláusula geral da boa-fé objetiva insculpida no art. 422 do Código Civil de 2002, os deveres anexos, ou de proteção, em que os contratantes devem se submeter.

A próxima seção dedica-se a explicar sobre a aplicação da boa-fé objetiva nos contratos, informando, assim, com mais detalhes essa integração e o surgimento dos deveres anexos ou de proteção.

\section{A BOA-FÉ OBJETIVA NOS CONTRATOS}

Como foi demonstrado na seção anterior, a boa-fé objetiva está integrada aos contratos. $\mathrm{O}$ art. 422 do Código Civil con- 
sagra a necessidade de as partes manterem, em todas as fases contratuais, sua conduta de probidade e lealdade.

Sobre a presença da boa-fé nos contratos, Sílvio de Salvo Venosa (2018, p. 22) expõe da seguinte forma:

Tanto nas tratativas como na execução, bem como na fase posterior de rescaldo do contrato já cumprido (responsabilidade pós-obrigacional ou pós-contratual), a boa-fé objetiva é fator basilar de interpretação. Dessa forma, avalia-se sob a boa-fé objetiva tanto a responsabilidade pré-contratual, como a responsabilidade contratual e a pós-contratual.

Apesar de o art. 422 do Código Civil mencionar somente conclusão e execução do contrato, a grande parte da doutrina e da jurisprudência entende pela aplicação da boa-fé objetiva tanto na fase pré-contratual quanto na pós-contratual. A respeito disso, Pablo Stolze Gagliano e Rodolfo Pamplona Filho (2013, p. 114) comentam o seguinte:

Por isso, embora imperfeita a atual redação legal, não hesitamos em afirmar que, com base no macroprincípio constitucional da dignidade da pessoa humana, a boa-fé objetiva deve ser observada também nas mencionadas fases anteriores e posteriores à celebração e cumprimento da avença. Pensar em sentido contrário seria defender, em última análise, que o sistema positivo brasileiro admitiria, em tais fases, a prática de condutas desleais, somente sancionando-as na fase contratual, o que nos parece um absurdo!

Então, é certo dizer que a boa-fé objetiva é aplicável em todas as fases contratual, inclusive sendo razão para apuração de responsabilidades.

Da possibilidade de responsabilização pela boa-fé objetiva nos contratos surgem, para os contratantes, os deveres anexos, 
laterais ou secundários, que devem ser observados no negócio jurídico pretendido. Esses deveres anexos são as outras funções da boa-fé objetiva originada pela integração com os contratos.

Para uma melhor compreensão dos deveres que a boa-fé objetiva gera com sua integração nos contratos, demonstram-se, primeiramente, os deveres anexos e, em seguida, os seus desdobramentos.

\subsection{Os deveres anexos, laterais ou secundários da boa-fé objetiva}

Deveres anexos, laterais ou secundários são obrigações que surgem ao ser realizado um negócio jurídico, visando à celebração de um contrato. A integração da boa-fé objetiva imposta aos contratos cria os deveres de cooperação e lealdade entre as partes.

Sobre isso, Judith Martins-Costa (2018, p. 572) ensina o seguinte:

É justamente para a aclaração deste "sentido total", que se torna imprescindível a referência ao princípio da boafé com valência integrativa, completando o conteúdo contratual com deveres que compõem, substancial e concretamente, o contrato: cooperar com a contraparte, em vista de alcançar o adimplemento, fim justificador do contrato; atuar com a lealdade exigível a uma pessoa proba; informar com a completude necessária para viabilizar um consentimento informado à proposição negocial ou a modificações que alterem, no iter contratual, as condições pactuadas; proteger os legítimos interesses da contraparte, de modo que o contrato não seja um fator produtor de danos injustos ao outro contratante ou ao seu patrimônio. Esses deveres passam a integrar a relação contratual, ainda que não expressamente previstos no instrumento. Complementam o seu conteúdo e pautam a conduta contratual correta. 
Em que pese existirem inúmeros deveres anexos originados pela boa-fé objetiva na integração com os contratos, o presente estudo limita-se àqueles deveres mais conhecidos pela doutrina, quais sejam: lealdade e confiança recíproca, cooperação ou assistência, informação, sigilo ou confidencialidade e proteção.

Dessa forma, passa-se a descrever cada um deles.

\subsubsection{Dever de lealdade e confiança recíproca}

Lealdade nada mais é do que a fidelidade aos compromissos assumidos dentro de uma relação negocial. Pablo Stolze Gagliano e Rodolfo Pamplona Filho esclarecem dizendo que: "A ideia de lealdade infere o estabelecimento de relações calcadas na transparência e enunciação da verdade, com a correspondência entre a vontade manifestada e a conduta praticada." (GAGLIANO; PAMPLONA FILHO, 2013, p.107).

A confiança é a crença na probidade moral de outrem. Assim, pode-se dizer que ela é conquistada pela prática reiterada de condutas leais.

Como resultado da integração da boa-fé objetiva, a lealdade e a confiança são deveres que devem ser construídos com a relação negocial pretendida. Ou seja, o que se almeja é o respeito mútuo no sentido de que uma parte não tenha a intenção de se prevalecer ou sobrepor em prejuízo da outra parte.

\subsubsection{Dever de cooperação ou assistência}

Em uma relação contratual, ambas as partes devem cooperar para o fiel cumprimento daquilo que foi acordado. Ou seja, o contrato é feito para ser cumprido e, assim, cabem às partes colaborar para o correto adimplemento da sua prestação.

Pablo Stolze Gagliano e Rodolfo Pamplona Filho ensinam que: "A esse dever se liga, pela negativa, consequentemente, o de não dificultar o pagamento, por parte do devedor, ou o rece- 
bimento do crédito, pelo sujeito ativo da relação obrigacional". (GAGLIANO; PAMPLONA FILHO, 2013, p.108).

Dessa forma, tem-se a necessária cooperação imposta pela boa-fé objetiva. Para isso, as partes devem prestar mútua assistência a fim de alcançar aquilo que foi acordado. E, ainda mais, devem as partes tomar todas as medidas necessárias para a satisfação do negócio celebrado.

\subsubsection{Dever de informação}

Pelo princípio da boa-fé objetiva, as partes contratantes têm o dever, na relação contratual, de informar, de avisar, de revelar, de esclarecer e de aconselhar sobre as informações do negócio jurídico celebrado, sendo que a omissão de certas informações essenciais ao negócio jurídico, em prejuízo de uma das partes, caracteriza uma espécie de trapaça.

Pablo Stolze Gagliano e Rodolfo Pamplona Filho (2013, p.109), sobre o dever de informação, conceituam da seguinte forma: "Trata-se de uma imposição moral e jurídica a obrigação de comunicar à outra parte todas as características e circunstâncias do negócio e, bem assim, do bem jurídico que é seu objeto, por ser imperativo de lealdade entre os contratantes."

Dessa forma, as informações e todos os dados do negócio celebrado devem ser explicados entre as partes da relação contratual, não se permitindo a omissão quanto a informações pertinentes. Isso visa garantir a lealdade dos contratantes, no sucesso do negócio, que objetiva o benefício de ambos.

\subsubsection{Dever de sigilo ou confidencialidade}

O dever de sigilo ou confidencialidade caracteriza-se no guardar sigilo sobre atos ou fatos dos quais se teve conhecimento em razão do contrato ou de negociação preliminares. São atos ou fatos que, na maioria das vezes, vêm do ofício profissional, podendo ser citado o que ocorre nas relações advo- 
catícias ou médicas. Também está presente nos contratos que envolvam segredo industrial e negociações comerciais.

Pablo Stolze Gagliano e Rodolfo Pamplona Filho (2013, p.112), para melhor compreensão, narram o seguinte exemplo:

Em um determinado contrato firmado entre as empresas OLIVEIRA e TIGÓ, para fornecimento de ração de pássaros, não se consignou cláusula no sentido de que as partes contratantes não poderiam, durante a vigência do contrato, ou mesmo após, divulgar dados ou informações uma da outra. Ora, ainda que não haja estipulação nesse sentido, é forçoso convir que a boa-fé objetiva impõe que se observe o dever de sigilo ou confidencialidade entre ambas.

Do exemplo doutrinário, uma parte não pode usar de uma confidencialidade para ver o prejuízo da outra parte. Trata-se de uma forma de deslealdade, uma vez que houve um vínculo de confiança com o objetivo de concretização da relação contratual.

Dessa forma, percebe-se que o dever de sigilo vem estabelecer uma proteção para as partes envolvidas no negócio jurídico, sendo, mais uma vez, verificados elementos característicos da boa-fé objetiva, como a lealdade e a confiança.

\subsubsection{Dever de proteção}

Do ensinamento de Judith Martins-Costa (2018, p. 598), ela dá o seguinte significado para essa modalidade de dever:

Os deveres de proteção se apresentam, de modo amplo e de modo estrito. No sentido amplo, abrangem condutas positivas e negativas; num sentido estrito, correspondem apenas ao dever negativo de proteção contra danos que podem advir do contrato considerado como fato social, já que não atinem diretamente aos interesses à prestação instrumentalizados pelo contrato como negócio jurídico. 
A princípio, as partes devem proteger o patrimônio e os direitos da personalidade de seu parceiro contratual. Caracteriza-se no dever de segurança e cuidado que as partes envolvidas devem observar.

O dever de proteção e cuidado é uma obrigação a mais no negócio jurídico pactuado. Ela é inerente ao objetivo comum das partes em obter êxito e benefício com o contrato celebrado. Dessa maneira, ambas as partes devem proteger e cuidar do objeto, da forma e das pessoas envolvidas no negócio jurídico.

O dever de proteção das partes do contrato é também considerado para resguardar a esfera jurídica de terceiros que eventualmente sejam atingidos pelo pacto celebrado. Ou seja, é necessário haver o dever de proteção para com o patrimônio e os direitos de terceiros que, por ventura, estejam envolvidos no negócio jurídico pactuado.

\subsection{Desdobramentos da boa-fé objetiva}

Entende-se como desdobramento da boa-fé objetiva a função de controle do exercício de um direito subjetivo. Dessa maneira, o titular de um direito deve exercê-lo dentro dos limites impostos pela boa-fé, sob pena de prática de abuso do direito.

Para facilitar a compreensão da função de controle imposta pela boa-fé objetiva, a maioria dos doutrinadores, como Pablo Stolze Gagliano, Rodolfo Pamplona Filho, Flávio Tartuce, Carlos Roberto Gonçalves, Elpídio Donizetti, Felipe Quintella, entre outros, utilizam-se de conceitos oriundos do direito comparado. Esses conceitos descrevem categorias de exercícios abusivos do direito. Nesta pesquisa, limitar-se-á a apresentar as principais categorias, que são: venire contra factum proprium, supressio, surrectio e tu quoque. 


\subsubsection{Venire contra factum proprium}

Consiste na vedação do comportamento contraditório, sendo que, na tradução, significa "vir contra um fato próprio". Com isso, quer-se dizer que, pelo princípio da boa-fé objetiva, é proibido que uma parte pratique uma determinada conduta na relação contratual e, posteriormente, queira adotar outra, oposta à primeira.

Exemplo de comportamento contraditório seria aquele credor que aceitou, durante a execução de pacto de trato sucessivo, o pagamento em lugar diverso do convencionado; diante disso, não pode surpreender o devedor com a exigência literal do contrato para alegar a existência de descumprimento. Também, apresenta-se, como exemplo, a situação articulada na doutrina de Elpídio Donizetti e Felipe Quintella (2016, p.484), como se vê:

Caio e Orlando celebram compra e venda de uma tela de um pintor famoso. Na execução do contrato, Caio aceita receber tela diversa da pactuada, do mesmo pintor. Posteriormente, ajuíza ação em face de Orlando alegando o inadimplemento do contrato, firme na cláusula que descrevia o objeto da compra e venda. Ocorre que, se Caio aquiesceu com o recebimento de coisa diversa no momento em que poderia tê-la enjeitado, não pode posteriormente adotar conduta oposta à praticada anteriormente.

Conforme o ensinamento de Sílvio de Salvo Venosa (2018, p. 24), a proibição de comportamento contraditório é "um imperativo em prol da credibilidade e da segurança das relações sociais e consequentemente das relações jurídicas que o sujeito observe um comportamento coerente, como um princípio básico de convivência." Como fundamento, tem-se um vínculo de confiança na conduta anterior da parte. Dessa forma, pode-se afirmar que a ocorrência do comportamento contraditório caracteriza um ato ilícito passível de indeniza- 
ção por perdas e danos nos casos de prejuízo (responsabilidade civil contratual).

\subsubsection{Supressio}

O termo "supressio" vem da palavra supressão. Esse termo vem definir a situação decorrente de um direito não exercido durante determinado lapso de tempo, o qual não poderá mais ser exercido por contrariar a boa-fé.

Elpídio Donizetti e Felipe Quintella (2016, p. 485) elucidam o conceito de supressio da seguinte forma:

Por força dos deveres objetivos de conduta impostos pelo princípio da boa-fé, não se admite que a parte que durante um longo período deixou de exercer um direito que lhe era atribuído, com isso gerando expectativas para a outra, venha posteriormente a exercê-lo. É que o não exercício do direito importa a sua supressio - "supressão", renúncia Tácita.

Em complementação à definição de supressio, Pablo Stolze Gagliano e Rodolfo Pamplona Filho (2013, p.121) afirmam o seguinte:

Assim, na tutela da confiança, um direito não exercido durante determinado período, por conta desta inatividade, perderia sua eficácia, não podendo mais ser exercitado. Nessa linha, à luz do princípio da boa-fé, o comportamento de um dos sujeitos geraria no outro a convicção de que o direito não seria mais exigido.

Como exemplo, tem-se no suposto contrato de locação uma cláusula que estabelece a imobiliária contratada como sendo o local de pagamentos dos aluguéis, mas, por conveniência, o inquilino, por longo período de tempo, acabou pagando diretamente ao locador, pois era mais cômodo para ambos, uma vez que o imóvel locado fica ao lado da residência do locador. 
Dessa situação, não se pode reestabelecer a cláusula que previa o pagamento diretamente para a imobiliária, ou seja, pelo princípio da boa-fé, ela foi suprimida.

Não se pode confundir a supressio com o instituto da prescrição, pois, enquanto esta subordina a pretensão apenas pela fluência do prazo, aquela depende da constatação de que o comportamento da parte não era mais aceitável, segundo o princípio da boa-fé. Também, diferencia-se da proibição do comportamento contraditório (venire contra factum proprium), uma vez que a supressio se consubstancia no mero não exercício do direito ou na tolerância da conduta diversa da pactuada.

\subsubsection{Surrectio}

Como afirmado por muitos doutrinadores, a surrectio é a outra face da supressio. Trata-se do nascimento de um direito oriundo da continuada prática de certos atos. Pablo Stolze Gagliano e Rodolfo Pamplona Filho diferenciam os dois conceitos da seguinte maneira: "Com efeito, se, na figura da supressio, vislumbra-se a perda de um direito pela sua não atuação evidente, o instituto da surrectio se configura no surgimento de um direito exigível, como decorrência lógica do comportamento de uma das partes." (GAGLIANO; PAMPLONA FILHO, 2013, p.122).

Elpídio Donizetti e Felipe Quintella (2016, p. 486) exemplificam a surrectio da seguinte forma:

Rui e Pontes celebram contrato de fornecimento mensal de frutas. Todos os meses, Rui arca com as despesas do envio das frutas, embora tal obrigação não houvesse sido ajustada. Passados meses de reiterada conduta, não permite a surrectio que Rui queira, a partir de determinado momento, exigir que Pontes cubra os custos da remessa. 
Enquanto na supressio tem a supressão de um direito não exercido, na surrectio tem o surgimento de um direito que, na maioria das vezes, vem de certas omissões no contrato celebrado. Esse direito que nasce tacitamente deve ser incorporado ao contrato por força do princípio da boa-fé objetiva.

\subsection{4. Ти quоque}

Entende-se por tu quoque a situação de uma parte que, tendo descumprido a lei ou o contrato, posteriormente pretende se valer do preceito descumprido em benefício próprio. Sobre a origem do termo, Pablo Stolze Gagliano e Rodolfo Pamplona Filho (2013, p.122) tratam da seguinte maneira: "Tu quoque, Brutus, Fili mi! A célebre frase, historicamente atribuída a Júlio César, pela constatação da traição de seu filho Brutus, dá nome também a um dos mais comuns desdobramentos do princípio da boa-fé objetiva."

Percebe-se que o termo Tu quoque se originou da conhecida história da traição do filho de Júlio Cesar, imperador romano. Carlos Roberto Gonçalves (2017, p. 61) referencia o conceito de tu quoque dizendo que "aquele que descumpriu norma legal ou contratual, atingindo com isso determinada posição jurídica, não pode exigir do outro o cumprimento do preceito que ele próprio já descumprira."

Como exemplo disso, recorre-se à situação hipotética apresentada por Elpídio Donizetti e Felipe Quintella (2016, p. 488):

Augusto empresta gratuitamente a César uma casa na praia, por um ano. Vencido o prazo, César deixa de restituir o bem, conquanto impelido a fazê-lo por Augusto. Ao receber a conta de energia, todavia, envia-a ao comodante para que este a pague, alegando já ter o comodato vencido. Considerando-se que as despesas da coisa, enquanto na posse do comodatário, não podem 
ser cobradas do comodante, Augusto defender-se-á do pedido de César baseado na vedação do tu quoque.

Do mostrado, não pode a parte favorecida pelo próprio descumprimento do contrato ou da norma exigir da parte contrária o comportamento dentro daquela cláusula ou norma violada por ele. Tal situação, evidentemente, é proibida pelo princípio da boa-fé objetiva.

\section{CONCLUSÃO}

Com o presente artigo, expôs-se um estudo teórico com a finalidade de responder como a boa-fé se inseriu no direito civil brasileiro e qual a sua relação com os contratos. O mencionado estudo apresentou as noções gerais do conhecimento da boa-fé para demonstrar a sua inserção no ordenamento civil e finaliza com a sua relação nos contratos.

Na primeira seção teórica da pesquisa (seção 2), tratou-se da origem, da definição, da normatização e da diferenciação da boa-fé. Na segunda seção teórica (seção 3), cuidou-se especificamente da boa-fé objetiva e suas funções no Código Civil de 2002. E, por fim, na última seção teórica (seção 4), abordou-se acerca da boa-fé objetiva nos contratos com os principais deveres anexos e desdobramentos.

A perquirição da inserção da boa-fé no ordenamento jurídico brasileiro foi abordada desde a primeira seção teórica da pesquisa. Foi demonstrado que a boa-fé no Código Civil de 2002 foi inserida de forma objetiva, seguindo, assim, o modelo que é praticado em outros países, sendo que isso veio a acrescer a boa-fé subjetiva já existente no Código Civil anterior, trazendo regras a todos os negócios jurídicos como as que já se aplicavam nas ações possessórias.

Na seção seguinte, são apresentadas as três funções inscritas pela norma civil material, arts. 113, 187 e 422, todos 
do Código Civil de 2002, que demonstram a inclusão objetiva da boa-fé. Essas funções são: interpretativas, de controle do exercício de um direito e de integração com os contratos, perfazendo verdadeiras manifestações da boa-fé objetiva sobre os negócios jurídicos.

A última seção da pesquisa mostra a relação da boa-fé objetiva nos contratos. Dessa relação surgem, para os contratantes, os deveres anexos e os desdobramentos da boa-fé objetiva. Como produto da relação da boa-fé objetiva nos contratos, tem-se a busca de um negócio jurídico cada vez mais justo, no qual se pretende garantir, para todos os envolvidos, o sucesso em suas tratativas, a satisfação da vontade mútua e o comprometimento moral e ético.

Em resposta à pesquisa, observa-se que a boa-fé se inseriu objetivamente no ordenamento civil para assegurar, nos negócios jurídicos, os comportamentos de lealdade, de confiança e de honestidade. Quanto à sua relação nos contratos, a boa-fé se tonou princípio a ser observado pelas partes envolvidas, no qual visa estabelecer condutas e deveres. Essas condutas e deveres, impostas pela boa-fé objetiva, garantem a proteção jurídica nas relações contratuais.

Dessa forma, o presente estudo pretende contribuir na discussão jurídica da aplicação da boa-fé objetiva no direito civil brasileiro, impulsionando a divulgação desse respeitável postulado moral. A pesquisa mostrou a existência de um mecanismo de proteção jurídica, criada pela boa-fé objetiva, importante na defesa da ética e da probidade nos negócios jurídicos contratuais.

Por fim, o tema é relevante para a comunidade jurídica em geral, mostrando-se a necessidade do seu amplo conhecimento. Para a sociedade brasileira, em que o ordenamento jurídico positivado é imposto, a boa-fé é um dos principais instrumen- 
tos na busca da convivência pacífica dentro do atual Estado Democrático de Direito.

\section{REFERÊNCIAS}

BRASIL. Lei $\mathbf{n}^{0}$ 8.078, de 11 de setembro de 1990. Dispõe sobre a proteção do consumidor e dá outras providências. Brasília, DF: Presidência da República, 1990. Disponível em: http://www.planalto.gov.br/ ccivil_03/leis/18078.htm. Acesso em: 22 abr. 2020.

BRASIL. Lei no 10.406 , de 10 de janeiro de 2002. Institui o Código Civil. Brasília, DF: Presidência da República, 2002. Disponível em: http://www.planalto.gov.br/ccivil_03/leis/2002/L10406compilada. htm. Acesso em: 22 abr. 2020.

BRASIL. Lei n⿳ 13.105, de 16 de março de 2015. Código de Processo Civil. Brasília, DF: Presidência da República, 2015. Disponível em: www.planalto.gov.br/ccivil_03/_ato2015-2018/2015/lei/113105.htm. Acesso em: 22 abr. 2020.

DINIZ, Maria Helena. Código civil anotado. 18. ed. São Paulo: Saraiva, 2017.

DINIZ, Maria Helena. Curso de direito civil brasileiro: teoria das obrigações contratuais e extracontratuais. 32. ed. São Paulo: Saraiva, 2016. v. 3.

DONIZETTI, Elpídio; QUINTELLA, Felipe. Curso didático de direito civil. 5. ed. São Paulo: Atlas, 2016.

GAGLIANO, Pablo Stolze; PAMPLONA FILHO, Rodolfo. Novo Curso de Direito Civil: Contratos Teoria Geral. 9. ed. São Paulo: Saraiva, 2013. v. 4.

GONÇALVES, Carlos Roberto. Direito civil brasileiro: contratos e atos unilaterais. 14. ed. São Paulo: Saraiva, 2017. v. 3.

MARTINS-COSTA, Judith. A boa-fé no direito privado. 2. ed. São Paulo: Saraiva, 2018.

TARTUCE, Flávio. Direito civil: teoria geral dos contratos e contratos em espécie. 11. ed. Rio de Janeiro: Forense, 2016. v. 3.

VENOSA, Sílvio de Salvo. Direito civil: contratos. 18. ed. São Paulo: Atlas, 2018. v. 3. 
ZANON JUNIOR, Orlando Luiz. Curso de filosofia jurídica. Florianópolis: Empório do Direito, 2016.

Recebido em: 25/04/2020

Aprovado em: 21/07/2020 